\title{
Serological prevalence of bovine viral diarrhoea (BVD-1) in non- vaccinated dairy cattle in the municipality of Realeza-Paraná
}

\section{Prevalência sorológica de diarreia viral bovina (BVD-1) em bovinos leiteiros não vacinados do município de Realeza-Paraná}

\author{
Anderson Bedin ${ }^{1}$; Tatiane Sott²; Fagner Luiz da Costa Freitas ${ }^{3}$; Iucif Abrão Nascif \\ Junior $^{3}$; Juliana Moreira Rozolen ${ }^{4}$; Carlos Eduardo Fonseca-Alves ${ }^{5 *}$; Fabiana Elias ${ }^{3}$
}

\section{Highlights:}

Cattle from the southwestern region of Paraná have positive BVD-1 serology.

Because Paraná is a border region, knowledge of the serological prevalence is crucial.

The purchase of animals from different farms was a risk factor for BVD-1.

\begin{abstract}
Bovine viral diarrhoea (BVD) is an infectious and contagious disease affecting cattle that is responsible for causing a wide range of clinical manifestations ranging from inapparent or subclinical infections to an acute and sometimes fatal disease known as mucosal disease. The agent that causes BVD is an RNA virus of the genus Pestivirus and family Flaviridae. BVD is transmitted in two different ways: horizontal, by secretions, and vertically in pregnant cows, where the cow transmits the virus to the foetus. The clinical signs depend on the affected animal, its immunological capacity, and in the case of pregnant females, the gestation phase. A gestational infection can result in several changes, such as congenital anomalies, abortion, or even the birth of so-called persistently infected (PI) animals, which are difficult to detect and have a very important epidemiological role within the herd. The southwest region of Paraná has the largest dairy basin in the state of Paraná and is predominantly composed of family farmers, many of whom adopt measures that increase the health risk of their herd. The objective of this study was to delineate the serological prevalence of non-vaccinated dairy cattle in the municipality of Royalty-PR in relation to the BVD-1 virus, as well as to evaluate the odds ratios, relative risk and risk attributable to the independent variables of breed, age and the community under study. To that end, 317 blood serum samples from non-vaccinated cows from 18 different farms, with various breeds and ages, were evaluated by virus neutralization for the detection of antibodies specific to BVD-1. The results showed that $17.03 \%$ of the animals (54/317) had positive BVD-1 serology, and $82.33 \%(15 / 18)$ of the farms had at least one positive animal. Animals of the Jersey breed and the Barra do Sarandi Line community had the highest epidemiological risks, with a strong association with BVD-1 infection.
\end{abstract}

Key words: Southwest Paraná. family farming. Sanitary. Reproduction.

1 Discente de Mestrado em Saúde, Bem-Estar e Produção Animal Sustentável na Fronteira Sul, Universidade Federal da Fronteira Sul, UFFS, Realeza, PR, Brasil. E-mail: ander.bedin12@gmail.com

2 Médica Veterinária, Serviço de Inspeção Municipal do Município de Capanema, Capanema, PR, Brasil. E-mail: tatiane_sott@ hotmail.com

3 Profs. Drs., Medicina Veterinária, UFFS, Realeza, PR, Brasil. E-mail: fagner.freitas@uffs.edu.br; iucif.junior@uffs.edu.br; elias. fabiana@gmail.com

4 Discente de Mestrado em Biotecnologia Animal, Faculdade de Medicina Veterinária e Zootecnia, FMVZ, Universidade Estadual Paulista, UNESP, Botucatu, SP, Brasil. E-mail: julirozolen@hotmail.com

5 Prof. Dr., Medicina Veterinária, Instituto de Ciências da Saúde, Universidade Paulista, UNIP, Bauru, SP, Brasil. E-mail: carlos. alves1@docente.unip.br

* Author for correspondence 


\section{Resumo}

A Diarreia Viral Bovina (BVD) é uma doença infectocontagiosa que acomete bovinos, responsável por causar uma ampla gama de manifestações clínicas, que variam desde infecções inaparentes ou subclínicas até uma doença aguda e, por vezes, fatal conhecida como Doença das Mucosas. O agente causal da BVD é um RNA vírus do gênero Pestivirus, e da família Flaviridae. A BVD é transmitida de duas formas distintas: horizontal, por secreções, e de forma vertical em vacas prenhes, ocorrendo transmissão da vaca para o feto. Os sinais clínicos dependem do animal acometido, de sua capacidade imunológica, e no caso de fêmeas prenhes, da fase de gestação que a mesma se encontra. Uma infecção no período gestacional pode resultar em várias alterações como: anomalias congênitas, aborto, ou até mesmo no nascimento dos chamados animais persistentemente infectados (PI), que são fontes de difícil detecção e que tem papel epidemiológico muito importante dentro do rebanho bovino. A região Sudoeste do Paraná possui a maior bacia leiteira do estado do Paraná, sendo composta, predominantemente, por pequenos produtores, sendo que muitos destes, adotam medidas que aumentam o risco sanitário do seu rebanho. Objetivou-se com este estudo, delinear a prevalência sorológica de bovinos leiteiros não vacinados do município de Realeza-PR, perante o vírus da BVD-1, bem como, avaliar odds ratio, risco relativo e atribuído as variáveis independentes: raça, idade e comunidade em estudo. Para tal, 317 amostras de soro sanguíneo provenientes de fêmeas não vacinadas, de 18 diferentes propriedades, raças e idades foram avaliadas por meio de vírus neutralização para a detecção de anticorpos específicos a BVD-1. Os resultados demonstram que $17,03 \%$ dos animais (54/317) foram positivos a sorologia de BVD-1, sendo que em $82,33 \%(15 / 18)$ das propriedades havia ao menos um animal positivo. Animais da raça Jersey e da comunidade de linha Barra do Sarandi, obtiveram os maiores riscos epidemiológicos, com grande associação a infecção de BVD-1.

Palavras-chave: Rebanho leiteiro. BVD. Fatores de risco. Sanidade.

\section{Introduction}

One of the diseases that directly affect dairy production and reproductive efficiency is bovine viral diarrhoea (BVD), which is considered one of the main diseases of cattle because it promotes significant economic losses in cattle farming worldwide (Ridpath, 2005). BVD is caused by a simple-chain RNA virus belonging to the family Flaviviridae and genus Pestivirus (Ridpath, 2005).

The BVD virus has two biotypes: noncytopathogenic (NCP) and cytopathogenic (CP). The NCP virus constitutes the majority of the field isolates and is associated with the various clinical manifestations of the infection, including the generation of persistently infected (PI) calves. On the other hand, the $\mathrm{CP}$ virus is present almost exclusively in cases of mucosal disease (MD) (Samara, Dias, \& Moreira, 2004). Infection of pregnant females may result in embryo loss, foetal loss, congenital malformations, stillbirth and the birth of weak calves (Grooms, 2004).
The BVD virus is transmitted both horizontally and vertically. Horizontal transmission occurs through direct contact between animals, mainly through the mucous membranes, including coitus, or indirectly through secretions, excretions, blood and fomites. PI animals are the main source of infection of the herd because they excrete the virus continuously and at high concentrations (Flores et al., 2005; Radostits, Gay, \& Hinchcliff, 2007). The vertical transmission mode affects seronegative cows, which occurs when the virus passes through the placenta. At this point, depending on the stage of pregnancy and the infecting biotype, either persistently infected, weak or unviable calves may be born, or the foetus is aborted (Flores et al., 2005; Radostits et al., 2007).

The consequences of using natural mating depend on the presence of the virus in the semen at the time of mating and the number of females mated (Quincozes et al., 2007). The BVD virus may be present in the semen of bulls both due to persistent 
infection and to acute transient postnatal infection of the bull; acute BVD infections of immunocompetent and seronegative bulls may cause the virus to be transferred through the semen in the viremia period (Radostits, Gay, Blood, \& Hinchcliff, 2000).

The main risk factors for BVD include the presence of persistently infected animals in the herd, mechanical milking, lack of veterinary care and an extensive rearing system (Quincozes et al., 2007). Laboratory tests are necessary for the final diagnosis of BVD. The most commonly used tests are indirect methods, such as the virus neutralization assay, which is a highly sensitive and specific test for the serodiagnosis of this disease (Radostits, Gay, Blood, $\&$ Hinchcliff, 2002). Diagnostic investigation in the herd is of utmost importance, as approximately 60 to $90 \%$ of the Brazilian herd is seropositive (Quincozes et al., 2007). The BVD virus causes reproductive losses, which culminate in major economic losses. The BVD virus has the ability to infect the foetus during the embryonic period, causing foetal death, abortion, low conception rate, infertility and the birth of persistently infected animals (Flores et al., 2005; Radostits et al., 2007).

The present study aimed to perform serological tests in the Realeza municipality using virus neutralization in cows older than 1 year of age to identify BVD-1-positive animals resulting from natural infections and to assess the associated epidemiological risk factors.

\section{Materials and Methods}

\section{Experimental site}

The present study was submitted for approval by the Ethics Committee on Animal Use (CEUA) under the protocol number 23205.003294 / 201498. Subsequently, blood samples were collected between 10 May and 4 August, 2014 in the Realeza municipality, southwest of Paraná. For this purpose, non-vaccinated dairy animals older than one year old were tested from 18 family farms located in 8 different communities of the municipality: Santa Terezinha Line, São José Line, Beija Flor Line, São Roque Line, São Miguel Line, Sanga da Aliança Line, Progresso Line and Barra do Sarandi Line. In general, the farms do not have data regarding health, zootechnical and reproductive control; thus, it was not possible to retrieve data such as date of birth, interval between births, length of service, conception rate, and number of abortions, stillbirths and neonatal mortality. Nevertheless, information on herd vaccination and history of reproductive events of the farms were obtained from the farmers.

\section{Animals}

A total of 317 blood serum samples from dairy animals were used. Between 9 and 23 bovine blood samples were collected per farm from an average of 17.6 bovines. All of the farms were dairy farms operating in a semi-intensive (17 farms) and intensive farming system (1 farm). Samples were composed of blood from females of the following breeds: Holstein (279 samples), Jersey (16 samples), Jersey/Holstein crossbreeds (21 samples) and Girolando ( 1 sample). The animal age ranged from 1 to 15 years old. Identification of the animals was performed using the number in the ear tag or the name of the animal.

\section{Serum sample}

Blood collection was performed by puncture of the coccygeal vein using a 40 x $12 \mathrm{~mm}$ disposable vacutainer ${ }^{\circledR}$ needle and $5.0 \mathrm{~mL}$ sterilized vacutainer ${ }^{\circledR}$ tubes without anticoagulant; the tubes were duly labelled with the number or name of the animal. Next, the blood samples were centrifuged at 3,000 rpm for 10 minutes to obtain the serum. The serum was stored in $1.0 \mathrm{~mL}$ microcentrifuge tubes (Eppendorf $^{\circledR}$, Hamburg, Germany), and these tubes were refrigerated at a temperature close to $4{ }^{\circ} \mathrm{C}$ prior to freezing at a controlled temperature of $-45^{\circ} \mathrm{C}$. The collected samples were sent to the Laboratory 
of Preventive Veterinary Medicine at the São Paulo State University - UNESP, Jaboticabal campus, São Paulo, Brazil, where the virus neutralization serological assay was performed to detect antibodies against BVD-1.

\section{Laboratory assays}

The serological study of the BVD-1 virus used the virus neutralization (VN) assay. This assay, also called serum $\mathrm{VN}$ or serum neutralization, is used to detect antibodies that have the ability to neutralize virus infectivity, i.e., neutralizing antibodies (Schiefer et al., 2006).

The serum samples were subjected to a $\mathrm{VN}$ assay using the technique described by the Manual for Standards for Diagnostic Tests and Vaccines (World Organization for Animal Health [OIE], 2018).

\section{Data analysis}

Epidemiological data analysis was performed by studying the association between seropositivity and the independent variables of age, breed and community. For this purpose, the odds ratio, relative risk and attributable risk were calculated. For statistical analysis, univariate analysis was performed using the chi-squared test of independence. The level of significance was set at $5 \%$, with confidence intervals of $95 \%$. All analyses were performed using the StatCalc function of the Epi Info $^{\text {TM }}$ software, version 7.2.0.1 (Center for Disease Control, Department of Health \& Human Services, USA).

\section{Results and Discussion}

Of the 317 serum samples subjected to the VN assay, 54 were positive, obtaining a titre above $1 / 10$. Thus, a serum prevalence of $17.03 \%$ was obtained among the samples tested for BVD-1. The present study was performed using the BVD-1
Singer strain. Most of the laboratories that perform serology through VN for the BVD virus use only BVD-1 strains, which are mostly reference strains of the virus, in addition to favouring the reading and interpretation of the results because they have a cytopathic effect on the cell wall (Sandvik, 2005). However, some studies have shown small differences between the results of $\mathrm{VN}$ assays against BVD-1 and BVD-2, as well as between their respective titres (Vogel et al., 2002; Lima, Vogel, Flores, \& Weiblen, 2005). Dias et al. (2010) found no significant difference $(p>0.05)$ in the proportion of cattle reactive to BVD-1 and BVD-2; thus, it is safe to use cytopathogenic strains only in an epidemiological survey.

The serological results are similar to those described by Nogueira (2003) in the Viçosa microregion in Minas Gerais (MG), where a serological prevalence of $14.3 \%$ was found. They are also close to the results found in Western Santa Catarina, with 28.5\% (Pasqualotto, Sehnem, \& Winck, 2015), and in the northwest region of Rio Grande do Sul, with $27.8 \%$ seropositivity (Possebon, Kaiser, \& Martins, 2015). These studies are similar to the present study in terms of methodology, and vaccinated animals were excluded from the analysis.

However, the results found in the present study differ from those found by Médici et al. (2000), who tested 937 beef and dairy cows from 81 herds of 74 municipalities in the state of Paraná and found a prevalence of $73.47 \%$. In the state of Rio Grande do Sul, Quincozes et al. (2007) tested 1,734 non-vaccinated dairy and beef cows belonging to 85 farms in different municipalities in the south of the state and found a prevalence of $66.32 \%$. In turn, Piovesan et al. (2013) and Becker et al. (2015) found prevalence rates of $85.4 \%$ and $55 \%$, respectively. However, in these studies, vaccinated and non-vaccinated animals were not differentiated. Regarding the national prevalence rates, in the northwest of the state of São Paulo and in the southern region of Minas Gerais the serological 
prevalence for the BVD virus was $57.18 \%$ (Samara et al., 2004) and 66.3\% (Dias et al., 2010). These data confirm the circulation of the virus in different farms throughout Brazil. The present study focused on small family farms, that is, farms in which the workforce is essentially made up of family members and lacks veterinary care. Therefore, these farmers should be included in BDV control programmes, and initiatives between universities and these farmers may be promising for the control of the disease.

Mainar-Jaime, Berzal-Herranz, Arias and Rojo-Vazquez, (2001), Nogueira (2003), Miranda (2012) and Possebon et al. (2015) attribute the low frequencies of positive animals relative to the national averages to the management practices used in the dairy herd. The purchase of infected or persistently infected animals is very low due to the dynamics used in small farms, such as the rearing of their own heifers to replace discarded cows and the disposal of males, in addition to the use of artificial insemination (AI). These data are consistent with those of the present study, where only $33.3 \%(6 / 18)$ of the farms reported purchasing animals from other herds, and only $11.1 \%(2 / 18)$ of them used natural mounting (NM) instead of AI. However, when studying 255 dairy herds in the municipality of Realeza - PR, Santos (2015) found that $63.92 \%$ of the farms used NM and $6.27 \%$ of these farmers performed both practices (AI and NM).

The introduction of new animals into the farm can be considered a risk factor because farmers generally do not take into account health aspects, such as tests, for such a transaction (Frandoloso et al., 2008). Houe (1999) states that the introduction of the virus into the herd occurs mainly through the purchase of PI animals or animals pregnant with PI foetuses in addition to contact with other animals in fairs, exhibitions or even through direct contact with other herds. Of the 18 farms in the current study, 15 $(82.33 \%)$ had at least one positive animal, with the number of positive animals in each farm ranging from 1 to 8 . Because this is a study involving small farms (family farming), it is important to emphasize the need to raise awareness among these farmers. Family farming is important in this region of the country; however, it can be responsible for maintaining the virus in the herd. The presence of positive animals in the herd has been previously described (Quincozes et al., 2007; Frandoloso et al., 2008; Possebon et al., 2015; Samara et al., 2004) and reinforces the need to identify positive animals for implementing prophylactic measures.

Samara et al. (2004) and Alexandrino (2008) concluded that the highest occurrences of BVDreactive animals are found in less-technified herds or mixed herds (milk and beef cattle). In turn, Quincozes et al. (2007) found a higher prevalence of BVD seropositive animals in mixed breeding systems. Of the animals with positive serology (Table 1), $57.41 \%$ had low titres $(\leq 1 / 40), 35.19 \%$ had average titres (between $1 / 80$ and $1 / 320$ ) and only $7.41 \%$ had high titres $(\geq 1 / 640)$. This titre distribution is similar to that found by Quincozes et al. (2007). However, they differ from those found by Becker et al. (2015), where most of the titres (63.1\%) were above $1 / 640$. Antibody titres may vary among laboratories depending on the strain of the virus and the cells used in the test (Grooms, Baker, \& Ames, 2006). 


\begin{tabular}{ccc}
\hline Titre & Number of Animals & $\mathbf{\%}$ \\
\hline $1 / 10$ & 7 & 12.96 \\
$1 / 20$ & 9 & 16.67 \\
$1 / 40$ & 15 & 27.78 \\
$1 / 80$ & 7 & 12.96 \\
$1 / 160$ & 8 & 14.81 \\
$1 / 320$ & 4 & 7.41 \\
$1 / 640$ & 4 & 7.41 \\
$1 / 1280$ & 0 & 0 \\
Total & $\mathbf{5 4}$ & $\mathbf{1 0 0}$ \\
\hline
\end{tabular}

The mean age of seropositive animals was 4.8 years. Older animals are more likely to be exposed to the virus and, therefore, have a higher probability of being infected (Mainar-Jaime et al., 2001; Thompson et al., 2006). However, in the present study, there was no statistically significant difference $(p<0.05)$ between the independent variable age and the dependent variable BVD-1 seropositivity, and $55.6 \%$ of the seropositive animals were younger than or equal to 4 years of age. Quincozes et al. (2007), Talafha, Hirche, Ababneh, Al-Majali and Ababneh (2008) and Alexandrino (2008) also did not find a significant correlation between BVD serological prevalence and age group.

Jersey animals had an odds ratio of 2.88, a relative risk of 2.21 and an attributable risk of BVD1 seropositivity of $19.5 \%$ when compared to animals of the other breeds studied (Holstein, crossbreed and Girolando). This correlation between the Jersey breed and BVD-1 virus positivity may be related to another risk factor, the use of natural mating, as $60 \%$ of the positive animals (3/5) came from the same farm that performs this practice. These results may be explained by the use of infected bulls for natural mating because transmission can occur through contaminated semen.

The independent variable community showed a statistically significant correlation with the dependent variable BVD-1 seropositivity in the Barra do Sarandi Line community. The calculated odds ratio was 4.50 , the relative risk was 16.80 and the attributable risk was $28.3 \%$, and $42.4 \%$ of the animals were seropositive in both farms belonging to this community. Regarding the risk factors that can be attributed to this case, one of the farmers reported the purchase of animals from other farms, but the use of natural mating on the respective farms was not observed. However, two of these farms reported reproductive problems such as placental retention and abortions.

The Progresso Line community with 2 farms and 32 animals tested was the only one that showed all cows to be seronegative. In one of these cases, animals had been purchased from other farms, and the other farm reported problems such as placental retention and return to oestrus. However, BVD is not the only cause of reproductive problems (e.g., return to oestrus, placental retention and abortion). Other communicable diseases such as leptospirosis, infectious bovine rhinotracheitis (IBR), neosporosis, brucellosis, campylobacteriosis and trichomoniasis can also be problematic, and it is therefore essential to establish a health programme for the prophylaxis of these diseases (Triana, Jimenez, \& Torres, 2012).

\section{Conclusion}

From the present epidemiological study, it can be concluded that antibodies generated from natural infections caused by the BVD-1 virus are present in 
dairy herds in the municipality of Realeza-PR. The difference between the data found here and those reported by other studies can be explained by the demographic characteristics of the herds, sample size and animal selection criteria. Notably, this study used animal serum samples regardless of their history of reproductive problems. This could have contributed to a higher prevalence rate.

The analysis of risk factors associated with BVD-1 virus infection shows that the greatest epidemiological risks were found in situations in which farmers purchased animals from other farms, as well as when they used NM, thus making these crucial points for the control and prophylaxis of the BVD virus in cattle herds in the municipality. The VN technique is an important tool for identifying viral circulation in the herd, and when identified, good management practices and vaccination should be applied as prophylactic measures.

\section{References}

Alexandrino, B. (2008). Modelo experimental com caprinos e cobaias para avaliação da eficácia de vacinas contra o Herpesvírus bovino tipo 1 e o vírus da Diarreia Viral Bovina tipos 1 e 2. Tese de doutorado, Universidade Estadual Paulista "Júlio de Mesquita Filho", Faculdade de Ciências Agrárias e Veterinárias, Jaboticabal, SP, Brasil.

Becker, A. S., Rodrigues, M. G., Orlandin, J. R., Menezes, P., Matos, C. S., Wilsmann, D. E., . . Rodrigues, P. R. C. (2015). Anticorpos neutralizantes contra o herpesvírus bovino tipo 1 e o vírus da diarreia viral bovina em bovinos vacinados e não vacinados da região sul do estado do Rio Grande do Sul. Science and Animal Health, 3(2), 209-220. doi: 10.15210/ sah.v3i2.5610

Dias, F. C., Médici, K. C., Alexandrino, B., Medeiros, A. S. R., Alfieri, A. A., \& Samara, S. I. (2010). Ocorrência de animais persistentemente infectados pelo vírus da diarréia viral bovina em rebanhos bovinos nos estados de Minas Gerais e São Paulo. Pesquisa Veterinária Brasileira, 30(11), 933-939. doi: 10.1590/S0100-736X2010001100006

Flores, E. F., Weiblen, R., Vogel, F. S. F., Roehe, P. M., Alfieri, A. A., \& Pituco, E. M. (2005). A infecção pelo vírus da Diarréia Viral Bovina (BVDV) no
Brasil - histórico situação atual e perspectivas. Pesquisa Veterinária Brasileira, 25(3), 125-134.doi: 10.1590/S0100-736X2005000300002

Frandoloso, R., Anzilieiro, D., Spagnolo, J., Kuse, N., Fiori, C., Scortegagana, G. T., . . . Kreutz, L. C. (2008). Prevalência de leucose enzoótica bovina, diarreia viral bovina, rinotraqueíte infecciosa bovina e neosporose bovina em 26 propriedades leiteiras da região Nordeste do Rio Grande do Sul, Brasil. Ciência Animal Brasileira, 9(4), 1102-1106.

Grooms, D. L. (2004). Reproductive consequences of infection with bovine viral diarrhea virus. Veterinary Clinics of North America: Food Animal Practice, 20(1), 5-19. doi: 10.1016/j.cvfa.2003.11.006

Grooms, D., Baker, J. C., \& Ames, T. R. (2006). Doenças causadas pelo vírus da diarréia viral bovina. In B. P. Smith. Medicina Interna de Grandes Animais (Chap. 3, pp. 707-714). São Paulo: Manole.

Houe, H.(1999). Epidemiological features and economical importance of bovine virus diarrhoea virus (BVDV) infections. Veterinary Microbiology, 64(2-3), 89107. doi: 10.1016/S0378-1135(98)00262-4

Lima, M., Vogel, F. S. F., Flores, E. F., \& Weiblen, R. (2005). Anticorpos neutralizantes contra o vírus da Diarréia Viral Bovina (BVDV): comparação entre um imunógeno experimental atenuado e três vacinas comerciais inativadas. Ciência Rural, 35(1), 230234. doi: $10.1590 / \mathrm{S} 0103-84782005000100039$

Mainar-Jaime, R. C., Berzal-Herranz, B., Arias, P., \& Rojo-Vazquez, F. A. (2001). Epidemiological pattern and risk factors associated with bovine viral-diarrhoea virus (BVDV) infection in a nonvaccinated dairy-cattle population from the Asturias region of Spain. Preventive Veterinary Medicine, 52(1), 63-73. doi: 10.1016/S0167-5877(01)00239-2

Médici, K. C., Moscardi, E., Jr., Vicente, K., Alfieri, A. F., \& Alfieri, A. A. (2000). Identification of antibodies against bovine virus diarrhea virus in beef and dairy cattle herds in Parana State. Virus Reviews and Research, 5(1), 145.

Miranda, I. C. S. (2012). Fatores associados a Infecção pelo vírus da Diarréia Viral Bovina e pelo Herpesvírus Bovino tipo 1 em rebanhos leiteiros da Mesorregião Centro-Oriental do Rio Grande do Sul. Dissertação de mestrado, Universidade Federal do Rio Grande do Sul, Porto Alegre, RS, Brasil.

Nogueira, F. S. (2003) Diagnóstico da infecção pelo vírus da Diarréia Viral Bovina em Propriedades da microrregião de Viçosa. Dissertação de mestrado, Universidade Federal de Viçosa, Viçosa, MG, Brasil. 
Pasqualotto, W., Sehnem, S., \& Winck, C. A. (2015). Incidência de Rinotraqueíte Infecciosa Bovina (IBR), Diarréia Viral Bovina (BVD) e Leptospirose em Bovinos Leiteiros da Região Oeste de Santa Catarina - Brasil. Revista em Agronegócio e Meio Ambiente, 8(2), 249-250. doi: 10.17765/2176-9168. 2015v8n2p249-270

Piovesan, M., Fernandes, M. H. V., Correa, R. A., Prado, M. H. J, Camargo, A. D., \& Rodrigues, P. R. C. (2013). Anticorpos contra o Herpesvírus bovino tipo 1, vírus da Diarréia Viral Bovina e vírus da Leucose Enzoótica Bovina na região da campanha do estado do Rio Grande do Sul. Science and Animal Health, 1(1), 38-49. doi: 10.15210/sah.v1i1.2609

Possebon, K. F., Kaiser, T. S., \& Martins, L. R. V. (2015, agosto) Soroprevalência da diarréia viral bovina da região noroeste do estado do Rio Grande do Sul. Anais do Seminário de Iniciação Cientifica, Ijuí, RS, Brasil, 23. Recuperado de https://www.publicacoeseventos. unijui.edu.br/index.php/salaoconhecimento/ article/ view/5374

Quincozes, C. G., Fischer, G., Hubner, S. O., D’ÁvilaVargas, G., Vidor, T., \& Brod, C. S. (2007) Prevalência e fatores associados à infecção pelo vírus da diarréia viral bovina na região sul do Rio Grande do Sul. Semina: Ciências Agrárias, 28( 2), 269-276. doi: 10.5433/1679-0359.2007v28n2p269

Radostits, O. M., Gay, C. C., Blood, D. C., \& Hinchcliff, K. W. (2000). Veterinary Medicine: a textbook of the diseases of cattle, sheep, pigs, goats and horses. London: W. B. Saunders.

Radostits, O. M., Gay, C., \& Hinchcliff, K. W. (2007). Veterinary Medicine: a textbook of the diseases of cattle, horses, sheep, pigs and goats. Edinburgh: Saunders Elsevier.

Radostits, O. M., Gay, C., Blood, D. C., \& Hinchcliff, K. W. (2002). Clínica Veterinária: um tratado de doenças de bovinos, ovinos, suínos, caprinos e equinos. Rio de Janeiro: Guanabara Koogan.

Ridpath, J. F. (2005). Practical significance of heterogeneity among BVDV strains: impact of biotype and genotype on U.S. control programs. Preventive Veterinary Medicine, 72(1-2), 17-30. doi: 10.1016/j.prevetmed.2005.08.003
Samara, S. I., Dias, F. C., \& Moreira, S. P. G. (2004). Ocorrência da diarreia viral bovina nas regiões sul do Estado de Minas Gerais e nordeste do Estado de São Paulo. Brazilian Journal of Medical and Biological Research, 41(6), 396-340. doi: 10.1590/ S1413-95962004000600007

Sandvik, T. (2005). Selection and use of laboratory diagnostic assays in BVD control programmes. Preventive Veterinary Medicine, 72(1-2), 3-16. doi: 10.1016/j.prevetmed.2005.08.015

Santos, N. L. dos, Jr. (2015). Perfil produtivo e reprodutivo das propriedades leiteiras do município de Realeza - PR. Trabalho de Conclusão de Curso de graduação em Medicina Veterinária, Universidade Federal da Fronteira Sul, Realeza, PR, Brasil.

Schiefer, P., Krametter, R. F., Schleiner, A., Loitsch, A., Golja, F., Mostl, K., \& Baumgartner, W. (2006). Seroprevalence of antibodies to ruminant pestiviruses in sheep and goats in Tyrol. Dtsch Tierarztl Wochenschr, 113(2), 55-58.

Talafha, A. Q., Hirche, S. M., Ababneh, M. M., AlMajali, A. M., \& Ababneh, M. M. (2008). Prevalence and risk factors associated with bovine viral diarrhea virus infection in dairy herds in Jordan. Tropical Animal Health and Production, 41(4), 499-506. doi: 10.1007/s11250-008-9214-6

Thompson, J. A., Leite, R. M. H., Gonçalves, V. S., Leite, R. C., Bandeira, D. A., Herrmann, G. P., . . . Lage, A. P. (2006). Spatial hierarchical variances and age covariance for seroprevalence to Leptospira interrogans serovar hardjo, BoHV-1 and BVDV for cattle in the State of Paraíba, Brazil. Preventive Veterinary Medicine, 76(3-4), 290-301. doi: 10.1016/j.prevetmed.2006.05.010

Triana, E. L. C., Jimenez, C. R., \& Torres, C. A. A. (2012, Janeiro). Eficiência reprodutiva em bovinos de leite. Anais da Semana do Fazendeiro, Viçosa, Minas Gerais, Brasil, 1. doi: 10.13140/2.1.4840.4485

Vogel, F. S. F, Flores, E. F., Weiblen, R., Mayer, S. V., Quadros, V. L., \& Oldoni, I. (2002). Magnitude, duração e especificidade da resposta sorológica em bovinos vacinados contra o vírus da diarreia viral bovina (BVDV). Ciência Rural, 32(1), 83-89. doi: 10.1590/S0103-84782002000100015

World Organization for Animal Health. (2018). Manual of diagnostic tests and vaccines for terrestrial animals. Paris: World Trade Organziation. 